\title{
PENGEMBANGAN PARIWISATA BERKELANJUTAN BERBASIS SUBAK SEBAGAI BAGIAN WARISAN BUDAYA DUNIA UNESCO DI DESA MENGESTA KABUPATEN TABANAN
}

\author{
Niluh Herawati \\ Email: hera.nehh11@yahoo.com
}

\begin{abstract}
As part of the cultural landscape of Bali, UNESCO World Cultural Heritage, Mengesta village in Tabanan district has a variety of natural and cultural potentials that can be developed as tourist attractions, including agricultural and its irigation system (subak). These can be managed properly in order to get benefits from tourism economy. This study analysis the development of sustainable tourism based on subak in the Mengesta village. The research applied qualitative and quantitative approaches. The study shows that subak has important and strategic position so it should be preserved in line with the objective of its designation as Word Cultural Heritage. However, the benefits of subak as a World Cultural Heritage have not been optimally perceived by the community in relation to the development of sustainable tourism in the village of Mengesta. Only a small proportion of people who enjoy the benefits of the status of subak as World Cultural Heritage in the context of tourism development. It is hoped that both the district and provincial governments help the community through funding and setting up regulations so that the development of subak as tourist attraction can be improved while keeping its sustainability.
\end{abstract}

Keywords: Mengesta village, subak, world cultural heritage, sustainable tourism.

\section{Pendahuluan}

Subak ditetapkan oleh UNESCO sebagai Warisan Budaya Dunia pada 29 Juni 2012 dengan label Cultural Landscape of Bali Province: the Subak System as a Manifestation of the Tri Hita Karana Philosophy (Lanskap budaya Bali: Sistem Subak sebagai Manifestasi Filosofi Tri Hita Karana). Penetapan subak sebagai Warisan Budaya Dunia (WBD) menjadi kebanggaan masyarakat Bali khususnya, dan masyarakat Indonesia pada umumnya (Kemendikbud, 2013:7; Windia dan Wiguna, 2013:205).

Namun di balik kebanggaan tersebut, sesungguhnya juga merupakan 
sebuah tantangan yang sangat besar bagi masyarakat Bali, karena Bali merupakan salah satu destinasi wisata penting di dunia. Menjadi tantangan, karena ada kewajiban bagi masyarakat Bali untuk melestarikan sistem subak, yang telah ditetapkan sebagai WBD, di tengah-tengah tingginya alih fungsi lahan pertanian ke non pertanian.

Wiguna (2008) menyatakan bahwa luas lahan sawah di Bali selalu berkurang, yang mencapai rata-rata 1.000 ha per tahun, karena adanya alih fungsi lahan pertanian ke non pertanian, terutama disebabkan oleh berkembangnya sektor pariwisata. Sejalan dengan Windia (dalam Antara 2013), yang menyatakan bahwa alih fungsi lahan pertanian selama lima tahun terakhir mencapai 5.00o hektar, atau rata-rata 1.00o hektar setiap tahun. Pada saat yang sama kunjungan wisatawan ke Bali meningkat ratarata $1,5 \%$ setiap tahun. ${ }^{1}$ Nampak dengan jelas bahwa pengembangan pariwisata di Bali telah banyak berkontribusi terhadap berkurangnya lahan pertanian yang merupakan bagian yang sangat penting dalam sistem subak.

Windia dan Wiguna (2013:32) mengatakan subak yang diperkirakan lahir pada abad ke-11 merupakan sebuah warisan masyarakat Bali yang memiliki nilai budaya yang sangat luar biasa. Melihat kenyataan tersebut, maka idealnya ada solusi yang dapat mensinergiskan pembangunan pariwisata dan pertanian, terlebih pada subak yang masuk dalam kawasan WBD Provinsi Bali. Sejalan dengan Perda Provinsi Bali No. 2 Tahun 2012 tentang Kepariwisataan Budaya Bali, bahwa sinergisme pembangunan sektor pariwisata dan pertanian sebagai sebuah budaya masyarakat Bali akan dapat memberikan kesejahteraan kepada masyarakat serta pelestarian budaya dan lingkungan.

Desa Mengesta, Kabupaten Tabanan, merupakan salah satu desa yang terletak di dalam kawasan Warisan Budaya Dunia (WBD) Provinsi Bali, sebagai bagian dalam lanskap subak Catur Angga Batukaru (Kemenbudpar, 2010:10). Sebagai salah satu bagian lanskap Catur Angga Batukaru dalam kawasan WBD, Desa Mengesta memiliki berbagai potensi alam dan budaya, termasuk sistem subak yang perlu mendapatkan perlindungan. Perlindungan dan pengelolaan subak sebagai WBD perlu dilakukan dengan baik dan berkelanjutan, agar memberi manfaat ekonomi bagi masyarakat serta terjaganya pelestarian alam dan budaya.

Warisan Budaya Dunia memiliki makna yang sangat penting bagi umat manusia dan sebagai sebuah warisan bagi generasi berikutnya. Situs warisan dunia adalah suatu tempat budaya dan alam, serta benda yang sangat berarti bagi umat manusia sehingga menjadi warisan bagi generasi berikutnya. ${ }^{2}$

Dinas Pariwisata Provinsi Bali. "Kedatangan Wisatawan Mancanegara yang Langsung ke Bali Berdasarkan Negara Pasar Utama" [Diunduh 8 September 2015]. Sumber : http://www.disparda.baliprov.go.id/ id/Statistik2

2 Wikipedia. "Situs Warisan Dunia UNESCO". [diunduh 22 Desember 2014]. Sumber: http://id.wikipedia.org/wiki/Situs_Warisan_Dunia_UNESCO 
Adanya predikat Warisan Budaya Dunia bagi subak di Bali, diharapkan dapat memberikan manfaat, khususnya bagi masyarakat lokal di sekitar kawasan. Seperti yang terjadi di kawasan wisata Jatiluwih sebagai bagian WBD Provinsi Bali, jumlah kunjungan wisatawan meningkat cukup signifikan sejak ditetapkan sebagai WBD oleh UNESCO tahun 2012. Meningkatnya kunjungan wisata ke Jatiluwih telah memberikan kontribusi yang cukup besar bagi pendapatan masyarakat Jatiluwih.

Oleh karena itu, pengembangan pariwisata di kawasan Desa Mengesta, juga memiliki peluang yang cukup besar karena Mengesta juga merupakan bagian dari WBD Provinsi Bali. Melalui pariwisata maka potensi-potensi lain yang ada di kawasan tersebut juga akan memperoleh peluang untuk berkembang sebagai kelengkapan penting dalam suatu sistem industri pariwisata.

Berdasarkan potensi, maka Desa Mengesta berpeluang untuk dikembangkan sebagai kawasan pariwisata berbasis pertanian (tourism based agriculture). Petani sebagai pelaku utama, dengan modal kesederhanaan dan keunikan kehidupan keseharian serta adat budayanya dapat menjadi daya tarik pariwisata, sehingga petani akan mendapat nilai tambah (value added) dalam kehidupan ekonominya. Melalui pendekatan ini diharapkan pembangunan kepariwisataan akan lebih diterima dan mampu memberikan manfaat ekonomi dan sosial budaya serta lingkungan.

Pengembangan pariwisata berbasis pertanian (agrowisata) merupakan model pengembangan pariwisata yang memiliki keterkaitan erat antara pertanian dan pariwisata. ${ }^{3}$ Agrowisata merupakan pengembangan pariwisata yang berbasis pertanian, dengan memanfaatkan aktivitas pertanian seperti membajak, menanam padi dan memanen sebagai objek wisata, daya tarik wisata dan atraksi wisata. Selain itu pemanfaatan hasil-hasil pertanian seperti beras, sayur dan buah untuk keperluan industri pariwisata seperti hotel dan restoran di suatu daerah tujuan wisata juga merupakan bagian dari pengembangan agrowisata.

Desa Mengesta juga memiliki daya tarik wisata alam dan budaya, khususnya panorama alam pegunungan yang terhampar dalam persawahan berterasering dengan hasil pertaniannya yang khas yaitu tanaman padi lokal beras merah organik. Desa Mengesta juga memiliki obyek wisata sumber air panas yang bermanfaat bagi kesehatan, serta terdapat kerukunan beragama di antara masyarakat. Selain itu, Desa Mengesta juga memiliki berbagai peninggalan sejarah seperti arca Ganesa, arca Lingga Yoni yang terdapat di Pura Luhur Batu Panes. Masyarakat Desa Mengesta juga masih menjalankan kehidupan pertanian dan ritualnya secara berkelanjutan (Wingarta, 2006:149). Semua potensi alam dan budaya tersebut sangat berpeluang

3 Pariwisata Bali. "Sinergisme Pertanian dengan Pariwisata". [Diunduh 13 November 2014). Sumber: http://asti-astiti.blogspot.com/2011/08/sinergikan-pertaniandengan-pariwisata.html 
untuk dikembangkan menjadi objek wisata, yang mampu meningkatkan pendapatan masyarakat setempat.

Sebagian besar kegiatan wisata yang telah berjalan di Desa Mengesta masih dikelola secara pribadi oleh pemiliki usaha, tanpa melibatkan masyarakat. Kondisi tersebut menyebabkan masyarakat kurang merasakan manfaat pembangunan pariwisata. Padahal pengelolaan kegiatan wisata akan sangat baik jika melibatkan dan memberdayakan masyarakat. Sebaliknya, tanpa memberdayakan masyarakat sekitar, maka keuntungan yang diperoleh tidak akan dirasakan oleh masyarakat, sehingga tidak bermanfaat bagi masyarakat setempat.

Predikat WBD memiliki manfaat strategis dalam pengembangan pariwisata berkelanjutan berbasis subak di Desa Mengesta. Pembangunan pariwisata yang terintegrasi dengan pertanian, sejalan dengan pelestarian budaya serta upaya melibatkan masyarakat dalam pengembangan sektor pariwisata di Desa Mengesta. Upaya tersebut di satu sisi akan mampu memperkecil dampak yang kurang menguntungkan dalam pengembangan sektor pariwisata, seperti terjadinya alih fungsi lahan pertanian, khususnya subak yang telah ditetapkan menjadi WBD. Di sisi lain akan mampu meningkatkan ekonomi masyarakat setempat.

Artikel ini membahas topik pengembangan pariwisata berkelanjutan berbasis subak di Desa Mengesta sebagai bagian dari Warisan Budaya Dunia Provinsi Bali yang telah ditetapkan UNESCO. Secara spesifik artikel ini mengangkat permasalahan berikut: 1) Bagaimana posisi subak sebagai basis agrowisata dalam pengembangan pariwisata berkelanjutan sebagai bagian dari WBD?; 2) Apa manfaat status WBD bagi masyarakat dalam pengembangan pariwisata berkelanjutan berbasis subak di Desa Mengesta sebagai bagian dari WBD?; 3) Bagaimana peran pemerintah setelah penetapan subak sebagai WBD dalam pengembangan pariwisata berkelanjutan berbasis subak di Desa Mengesta. Artikel ini diharapkan dapat memberikan kontribusi pengetahuan dan rekomendasi didalam menjaga keberlanjutan pelestarian dan pemanfaatan situs warisan budaya dunia, khususnya subak dalam lansekap budaya Provinsi Bali.

\section{Teori dan Metode}

Setidaknya terdapat tiga teori yang digunakan dalam penelitian ini. Ketiga teori tersebut antara lain: (1) Teori persepsi yang digunakan untuk mengkaji dan menganalisis tingkat pengetahuan masyarakat tentang WBD dan peran pemerintah setelah penetapan WBD; (2) Teori pariwisata berbasis masyarakat (community based tourism) untuk mengkaji manfaat status WBD dalam pengembangan pariwisata berkelanjutan serta keterlibatan masyarakat Desa Mengesta; dan (3) Teori perencanaan pariwisata untuk mengkaji dan menganalisis posisi subak sebagai basis agrowisata dalam 
pengembangan pariwisata Desa Mengesta.

Terdapat lima metode atau cara yang digunakan untuk mengumpulkan data primer dalam penelitian ini, yaitu: (1) Survei digunakan untuk mengumpulkan data tentang persepsi dan pengetahauan masyarakat dalam pengembangan pariwisata berkelanjutan berbasis subak; (2) Focus Group Disscusion (FGD), digunakan untuk mengumpulkan semua data yang berkaitan dengan pengelolaan potensi pariwisata oleh berbagai stakeholder; (3) wawancara mendalam (in-depth interview) digunakan untuk mengumpulkan data yang berkaitan dengan pengelolaan pariwisata secara lebih mendetail; (4) pengamatan lapangan digunakan untuk mengetahui dengan lebih baik tentang kondisi riil di tingkat lapangan yang berkaitan dengan pengelolaan pariwisata berbasis subak; dan (5) mapping (pemetaan) digunakan untuk mengumpulkan semua data potensi dan daya tarik wisata di Desa Mengesta. Selanjutnya data sekunder dikolesi melalui studi pustaka dari berbagai sumber terkait, seperti Dinas Pariwisata, Dinas Kebudayaan dan Dinas Pertanian, maupun sumber lainnya yang bisa dipercaya.

Data penelitian melalui survei dikumpulkan atau bersumber dari 60 orang responden, yang ditentukan secara acak sederhana (simple random sampling) menurut Steel dan Torrie (1991:45). Dari 6o orang responden tersebut diharapkan telah mewakili penduduk Desa Mengesta, untuk memberikan informasi atau jawaban dari daftar pertanyaan terstruktur yang telah disiapkan melalui daftar pertanyaan atau kuisioner penelitian. Pengambilan responden sebanyak 60 orang dimungkinkan karena karakteristik sosial budaya dan mata pencaharian masyarakat Desa Mengesta relatif homogen. Sehingga 60 orang responden tersebut akan mampu mencerminkan atau mewakili masyarakat Desa Mengesta untuk memberikan informasi yang diperlukan peneliti. Selain itu keterbatasan biaya serta waktu dan lokasi juga menjadi pertimbangan penulis dalam menetapkan jumlah responden penelitian. Data survei dianalisis dengan menggunakan metode analisis distribusi frekuensi (Bungin, 2008).

Pemilihan peserta Focus Group Disscusion (FGD) disesuaikan dengan topik diskusi dan latar belakang masyarakat. Peserta FGD adalah tokoh masyarakat yang terlibat langsung terhadap berbagai kegiatan dan kebijakan yang berkaitan dengan pembangunan pariwisata dan pertanian di Desa Mengesta. Oleh karena itu FGD dilakukan dengan melibatkan masyarakat/ petani, perangkat desa, pelaku pariwisata, pokdarwis dan kelian subak.

Selanjutnya data yang dikumpulkan melalaui wawancara mendalam (indepth interview) bersumber dari tokoh masyarakat dan informan tertentu yang dianggap mengetahui dan memahami dengan baik segala aspek yang behubungan dengan pengembangan pariwisata di Desa Mengesta terkait dengan tujuan penelitian. Nara sumber atau informan tersebut ditentukan secara purposive, yaitu Kepala Bidang Pengkajian dan Pengembangan Dinas 
Pariwisata Provinsi Bali, Dinas Kebudayaan dan Pariwisata Kabupaten Tabanan, Perbekel Desa Mengesta, Kelian subak, pelaku pariwisata dan Ketua kelompok sadar wisata (pokdarwis) karena diasumsikan menguasai materi dan dapat memberikan informasi sesuai dengan tujuan penelitian.

Pengamatan lapangan dilakukan secara langsung oleh peneliti di kawasan Desa Mengesta, untuk megumpulkan berbagai infomasi dan data yang selanjutnya didokumentasikan dalam bentuk foto. Data tersebut meliputi potensi pariwisata, aktivitas masyarakat atau atraksi pariwisata yang ada di kawasan Desa Mengesta dan merupakan informasi penting untuk mengatahui realitas lapangan yang berkaitan dengan pengembangan dan pemanfaatan potensi pariwisata.

Koleksi data melalui mapping (pemetaan) digunakan untuk mengumpulkan semua data potensi dan daya tarik wisata di Desa Mengesta. Data tersebut merupakan data spacial, yang dikumpulkan dengan menggunakan Geo Positioning Satelit (GPS). Melalui cara tersebut akan diketahui posisi koordinat dari setiap potensi dan objek wisata di Desa Mengeta.

Pendekatan penelitian dilakukan secara kualitatif dan kuantitatif. Pendekatan kualitatif untuk mendeskripsikan dan menjelaskan fenomena atau hubungan antar fenomena yang diteliti secara sistematis, faktual dan akurat. Sementara pendekatan kuantitatif digunakan untuk menganalisis data hasil survei terhadap masyarakat di Desa Mengesta. Data yang dianalisis merupakan variabel yang berhubungan dengan pengetahuan masyarakat, manfaat status WBD bagi masyarakat, pengelolaan potensi dan daya tarik wisata, serta keterlibatan masyarakat dan peran pemerintah dalam pengelolaan pariwisata di Desa Mengesta.

\section{Gambaran Umum}

Secara administrative, Desa Mengesta terdiri dari tujuh Banjar Dinas yaitu: Banjar Dinas Piling Kawan, Banjar Dinas Piling Kanginan, Banjar Dinas Kedampal, Banjar Dinas Belulang, Banjar Dinas Wongaya Betan, Banjar Dinas Mengesta, dan Banjar Dinas Piling Tengah (Pemda Kabupaten Tabanan, 2013:7).

Desa Mengesta terletak di Kecamatan Penebel, Kabupaten Tabanan, merupakan salah satu desa yang memiliki hawa sangat sejuk dan lahan sawah yang cukup luas yang terbagi menjadi tiga kawasan subak yaitu subak Wongaya Betan (90 ha), subak Kedampal atau Paselatan (120 ha) dan subak Piling (150 ha). Sebagian besar kondisi lahan sawah di Desa Mengesta bertopografi miring hingga landai, hanya sebagian kecil yang bertopografi datar. Kondisi tersebut sangat menarik karena menyajikan panorama alam perbukitan dengan sawah berteras yang indah sehingga dapat digunakan sebagai atraksi wisata lintas alam (trekking, cycling ataupun dengan ATV) 
dengan jalur-jalur alternatif yang melintasi eksositem subak, sehingga mampu menyajikan pemandangan alam yang menarik.

Sebagian besar masyarakat Desa Mengesta memiliki mata pencaharian utama sebagai petani. Secara umum tingkat pendidikan masyarakat Desa Mengesta relatif masih rendah, karena sebagian besar hanya mengenyam pendidikan sampai tingkat sekolah dasar (SD). Meskipun ada beberapa orang yang sudah menempuh pendidikan sampai tingkat SMP, SMA dan perguruan tinggi namun jumlahnya relatif sangat sedikit.

Aksesibilitas jalan di Desa Mengesta masih dalam kondisi yang kurang baik, karena banyak jaringan jalan yang rusak dan menyebabkan sulitnya aksesibilitas ke tempat-tempat yang menjadi potensi daya tarik wisata. Kondisi tersebut menyebabkan wisatawan datang dan melewati tempat atau daerah tersebut relatif sedikit. Padahal panorama alam dan persawahan yang dimiliki Desa Mengesta tidak kalah indahnya dengan Jatiluwih yang sudah sangat terkenal.

\section{Subak sebagai Basis Agrowisata Berkelanjutan}

Subak sebagai potensi pariwisata dapat dilihat dari tiga aspek, antara lain: (1) aspek fisik (alam), subak menghasilkan pemandangan yang sangat indah dengan terasering sebagai sebuah ekosistem subak; (2) aspek biotik, ekosistem subak menghasilkan berbagai jenis tanaman, terutama padi lokal maupun padi varietas unggul, sayuran serta pengembangan berbagai jenis pertanian organik, termasuk padi organik; dan (3) aspek sosial budaya, subak telah menghasilkan berbagai bentuk kegiatan sosial dan budaya masyarakat seperti budaya pertanian, berbagai jenis upacara yang berkaitan dengan subak. Dari ketiga aspek tersebut akan memberikan berbagai peluang pengembangan komoditas pariwisata, seperti trekking pada ekosistem subak, atraksi membajak, atraksi menanam padi sawah, wisata budaya yang berkaitan dengan upacara di subak dan sebagainya.

Hasil pemetaan terhadap potensi wisata nampak adanya beberapa potensi daya tarik wisata di Desa Mengesta, yang dapat dikelola dan dikembangkan menjadi daya tarik wisata. Potensi daya tarik wisata tersebut antara lain: 2 (dua) sumber air panas Kedampal sebagai wisata alam; 3 (tiga) bangunan gereja di Dusun Piling dan beberapa pura menggambarkan kerukunan antar umat beragama; sebuah penginapan serta areal sawah yang digunakan jalur trekking oleh pelaku pariwisata di Desa Mengesta. Potensi wisata tersebut dapat menjadi daya tarik wisatawan jika dikemas dan dikelola dengan baik.

Untuk mendorong terjadinya aktivitas wisata maka ketersediaan atraksi merupakan daya tarik yang akan melahirkan motivasi atau keinginan bagi wisatawan untuk melihat dan mengunjungi destinasi Desa Mengesta (Something to see). Melalui hasil diskusi FGD bersama tokoh masyarakat, kelompok sadar wisata (pokdarwis), dan perangkat desa serta masyarakat, 


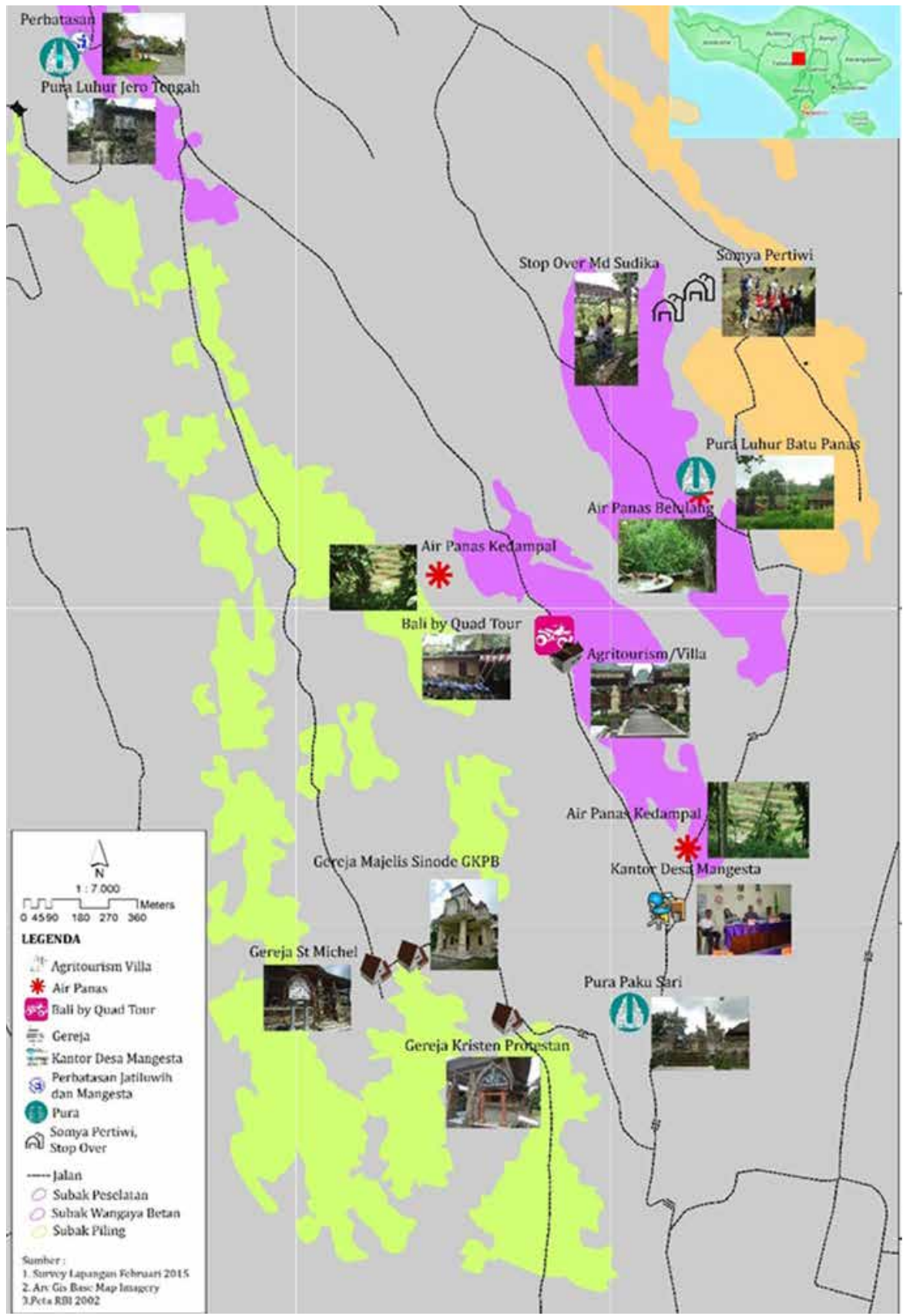

Foto 1. Peta potensi wisata Desa Mangesta.

menunjukkan adanya pemahaman dan kesadaran masyarakat akan potensi dan daya tarik yang dimiliki Desa Mengesta (Foto 1). Dari Foto 1, nampak bahwa Desa Mengesta, selain memiliki dengan pemandangan yang sangat indah, juga memiliki berbagai potensi pariwisata lainnya seperti air panas 
alam, tempat ibadah, peninggalan sejarah, atraksi pariwisata seperti membajak, dan trekking.

Desa Mengesta memiliki kekayaan alam yang indah yang tidak kalah dengan ekosistem subak di kawasan Jatiluwih dan beragam budaya yang dapat menjadi daya tarik wisatawan jika dikelola dan dikembangkan dengan baik. Salah satu kekayaan alam dan budaya tersebut adalah ekosistem subak yang sangat berpotensi untuk dikembangkan sebagai daya tarik wisata. Subak memiliki nilai-nilai yang dapat dilihat atau nilai nyata (tangible value) seperti ekosistem subak sebagai penghasil pangan (padi dan sayuran), dan nilai-nilai yang tidak nyata (intangible value) seperti fungsi subak yang berkaitan dengan upacara keagamaan. Selain itu subak juga sebagai sumber inspirasi seni seperti seni lukis, seni tari, subak juga sebagai media pendidikan lingkungan dan kawasan konservasi alam.

Agrowisata menjadi salah satu wujud keberlanjutan sistem subak dengan menempatkan sektor primer (pertanian), ke dalam sektor tersier (pariwisata). Berbagai kiat untuk mengkaitkan sektor pertanian dengan sektor pariwisata di Bali tampaknya belum berhasil dengan baik. Dengan perencanaan dan pengembangan yang terpadu dari masyarakat, stakeholders dan pemerintah diharapkan sektor pariwisata akan mampu meningkatkan kualitas sektor pertanian sekaligus sebagai wujud pelestarian warisan budaya.

Desa Mengesta memiliki hamparan sawah yang terdiri dari tiga eksosistem, yaitu: ekosistem subak Paselatan, ekosistem subak Wangaya Betan dan ekosistem subak Piling. Ketiga ekosistem subak tersebut memiliki pemandangan yang sangat indah, terlebih pada saat padi yang ditanam petani sedang menguning, pertanda panen segera akan tiba. Selain itu, subak juga memiliki keunikan dalam berbagai ragam budaya yang berkaitan dengan upacara dan budaya subak sehingga sangat layak dijadikan sebagai agrowisata.

Berdasarkan hasil analisis data menunjukkan bahwa sebagian besar (70,0\%) masyarakat menginginkan model pariwisata pertanian (agrowisata) berbasis subakyang perlu dikembangkan di desa tersebut. Selain itu, sebanyak 15,0\% masyarakat Desa Mengesta juga menginginkan pengembangan wisata alam air panas sebagai wisata alam. Selanjutnya sebanyak 6,7\% masyarakat menginginkan atraksi pariwisata berbasis pertanian, dan 5,0\% menginginkan model pariwisata modern lengkap dengan fasilitas seperti vila, hotel dan restoran, sisanya sebanyak 3,3\% menginginkan model pariwisata pegunungan.

Hasil analisis menunjukkan bahwa pariwisata yang ingin dikembangkan masyarakat sejalan dengan penetapan subak sebagai WBD. Karena pengembangan agrowisata berbasis subak searah dengan inti penetapan subak sebagai WBD, yaitu di satu sisi agar subak tetap lestari sepanjang waktu, dan di sisi lain terjadi peningkatan pendapatan masyarakat 


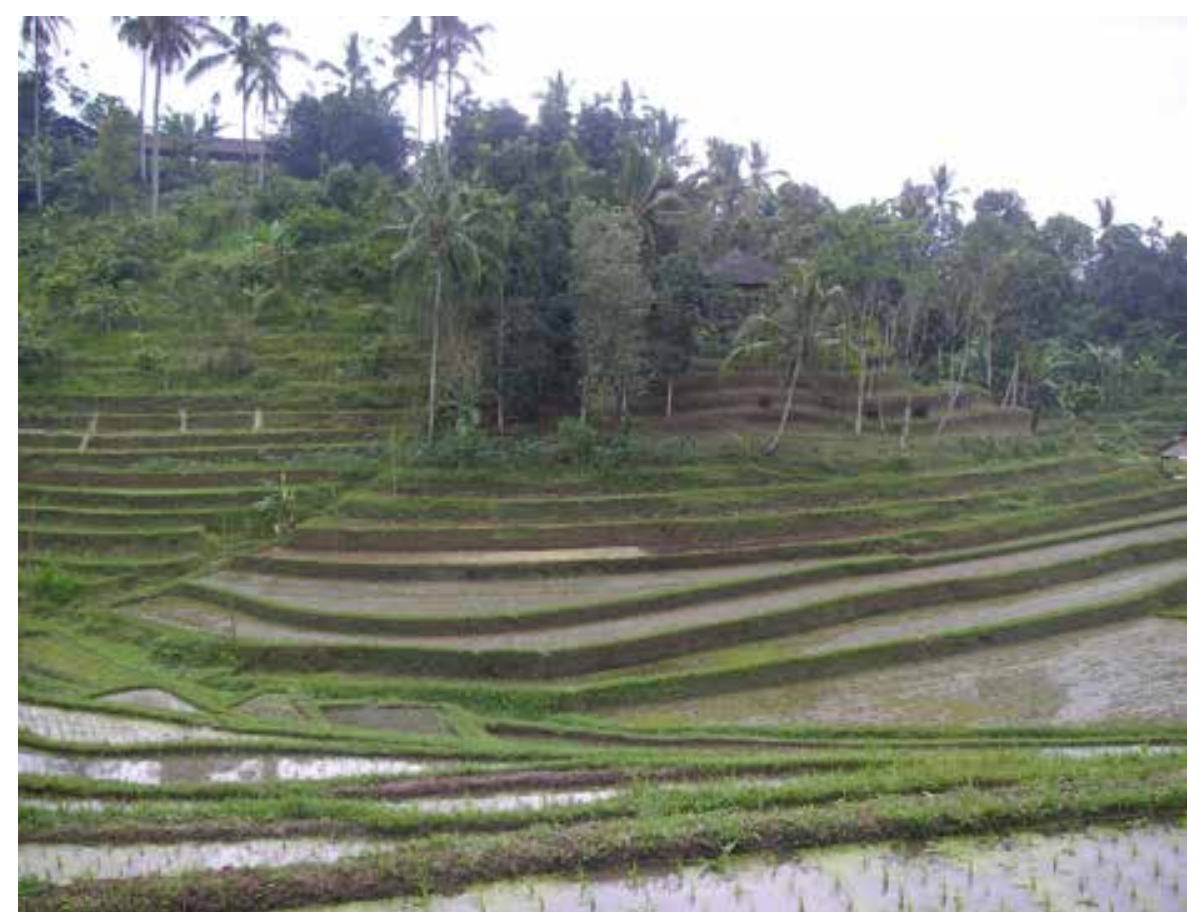

Foto 2. Peta Potensi dan daya tarik wisata Desa Mengesta

pengelola sistem subak. Dengan kata lain bahwa peningkatan pendapatan dan kesejahteraan petani pengelola sistem subak harus dilakukan tanpa merusak ekosistem subak, apalagi menghilangkan sistem subak itu sendiri. Karena jika sistem subak hilang sebagai akibat pengembangan pariwisata, maka jelas hal tersebut sangat bertentangan dengan tujuan penetapan subak sebagai WBD Provinsi Bali.

Subak Kedampal memiliki sawah berteras yang tertata dengan rapi, sehingga melahirkan sebuah pemandangan yang sangat indah (Foto 2). Di tengah ekosistem subak, mengalir air irigasi melalui saluran air irigasi berkelok-kelok, sehingga menambah nuansa keindahan yang dihasilkan oleh ekosistem subak Kedampal.

Kawasan Subak Piling telah digunakan sebagai jalur trekking dan wisata alam dengan menggunakan ATV yang dikelola oleh Bali By Quad (BBQ). Rute perjalanan dengan menggunakan ATV. Melewati jalan yang berkelokkelok di tepi sungai dan di kawasan ekosistem subak, nampak memberikan pengalaman tersendiri bagi wisatawan. Selain itu, sebagian besar petani masih memanfaatkan ternak sapi dan atau kerbau sebagai tenaga kerja dalam pengolahan lahan sawah, yang berpeluang sebagai atraksi wisata pertanian. Kondisi tersebut mengindikasikan bahwa kawasan ekosistem subak Piling memiliki potensi yang cukup besar untuk dikembangkan sebagai wisata 
alam dan wisata pertanian, yang sesuai dengan ditetapkannya subak sebagai Warisan Budaya Dunia.

Subak Wangaya Betan, yang terletak di kawasan Desa Mengesta juga merupakan salah satu subak dari 14 subak yang ada di kawasan Catur Angga Batukaru. Sejak tahun 2006 subak Wangaya Betan telah mengembangkan pertanian organik khususnya padi organik melalui teknologi pertanian terintegrasi. Pada tahun 2009 Subak Wangaya Betan melalui kelompok tani Somya Pertiwi telah mendapatkan sertifikat organik dari lembaga sertifikasi organik LeSOS di Mojokerto. Sehingga subak Wangaya Betan tidak hanya dikenal sebagai produsen beras organik, namun juga dapat sebagai pelaku di sektor pariwisata.

Jika hal tersebut dapat terus dikembangkan, maka petani tidak hanya sebagai obyek atau penonton aktivitas pariwisata, karena subak Wangaya Betan juga dapat dikembangkan sebagai basis pengembangan agrowisata berbasis ekosistem subak. Sehingga dapat dikatakan tidak banyak wilayah atau daerah yang memiliki kelebihan seperti Desa Mengesta.

Kegiatan pertanian dan berkaitan dengan sistem subak, yang dapat dijadikan komoditas wisatawan antara lain:

Membajak dengan menggunakan ternak sapi atau kerbau. Wisatawan dapat menikmati unsur alam dan kegiatan pertanian dalam aktivitas wisata yang memberikan sebuah pengalaman baru bagi wisatawan.

Menanam padi yang dilakukan oleh wisatawan juga dapat menjadi pengalaman baru bagi seorang wisatawan, sehingga sejalan dengan prinsip pengembangan agrowisata yang mengedepankan sebuah pengalaman (experiences) sebagai sebuah produk wisata. Setelah mereka mengeluarkan energi untuk mendapatkan pengalaman baru tersebut, selanjutnya wisatawan dapat disuguhkan dengan minuman ringan berupa air kelapa muda yang kemungkinan besar juga belum pernah mereka nikmati di negara asalnya.

Atraksi mengolah dan mengangkut pupuk organik yang berasal dari limbah ternak juga dapat dijadikan salah satu atraksi wisata pertanian yang berkaitan dengan sistem subak.

Panen padi lokal secara tradisional oleh seorang petani juga merupakan salah satu potensi atraksi wisata yang telah dikembangkan oleh masyarakat petani subak Wangaya Betan, Desa Mengesta.

Pasca panen dan pengolahan padi menjadi beras serta pengolahan pangan berbasis beras organik, seperti pengolahan beras merah menjadi teh beras merah, kopi beras merah dan lainnya, yang dapat digunakan sebagai souvenir oleh wisatawan.

Melakukan trekking dengan mengelilingi kawasan atau ekosistem subak Wangaya Betan.

Berbagai potensi wisata yang berkaitan dengan sistem dan ekosistem subak tersebut, nampak dengan jelas dapat dikembangkan menjadi sebuah 


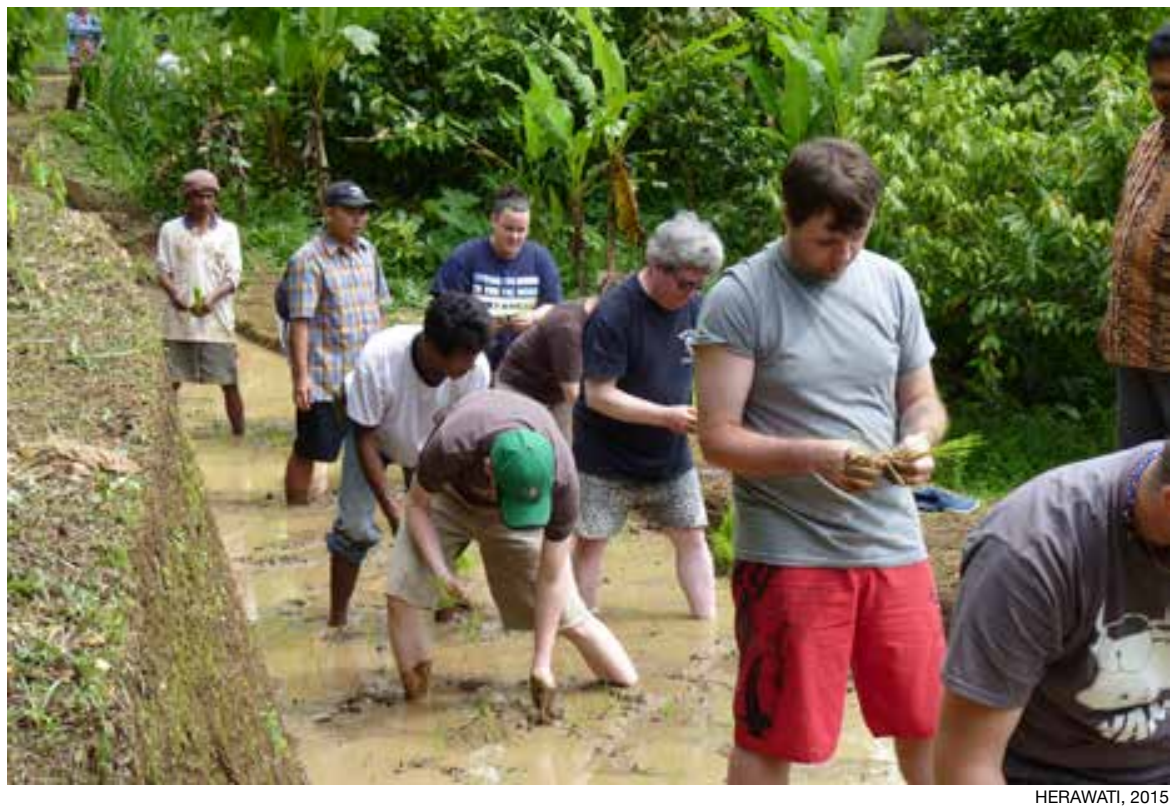

Gambar 3. Atraksi menanam padi, salah satu aktivitas pertanian di Subak Wangaya Betan yang menarik bagi wisatawan.

objek wisata pertanian (agrowisata) yang sangat menarik bagi wisatawan. Serta menunjukan posisi subak yang sangat penting dan strategis dalam pengembangan pariwisata berkelanjutan berbasis subak di Desa Mengesta. Sehingga sangat relevan dengan predikat subak sebagai Warisan Budaya Dunia di Provinsi Bali.

Desa Mengesta memiliki sumber air panas alam, yang salah satunya adalah Air Panas Belulang. Air Panas Belulang berada di tengah hamparan persawahan yang luas membentang di kawasan subak Paselatan. Tempatnya sangat menyenangkan, bisa dibayangkan ditengah-tengah hamparan persawahan yang kini masuk menjadi WBD terdapat sumber air panas yang konon bisa menyembuhkan berbagai penyakit kulit dan menyehatkan kembali badan yang letih. Selain sebagai tempat pemandian dan pengobatan penyakit kulit, Air Panas Belulang juga digunakan sebagai tempat penyucian diri sebelum melakukan persembahyangan ke Pura Luhur Batu Panes, yang sangat berpeluang dijadikan sebagai rangkaian wisata spiritual.

Daya tarik wisata lain yang memadukan unsur alam dan teknologi juga sudah ada dan cukup berkembang di Desa Mengesta ini. Dari potensi alam yang dimiliki dapat dikembangkan wisata trekking, bersepeda, outbound dan meditasi, seperti yang dikelola oleh Bali By Quad (BBQ). Kemasan paket wisata yang dilakukan juga sebagai upaya mereka dalam mendukung pelestarian terhadap subak dan pemberdayaan terhadap masyarakat lokal. Mengenai paket wisata yang tersedia di BBQ menurut Manajer Operasional 


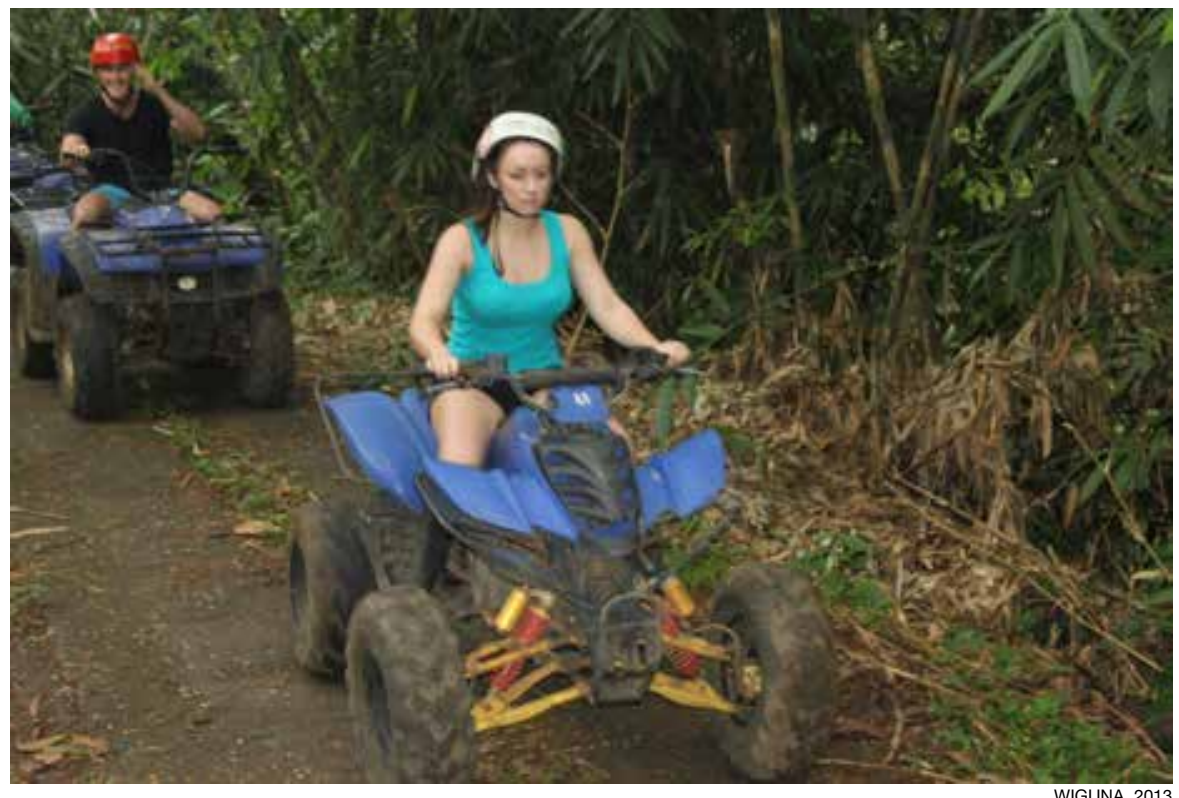

Foto 4. Wisatawan sedang menikmati perjalanan wisata dengan kendaraan ATV di kawasan subak Piling.

BBQ I Wayan Puja Astawa cukup beragam, yaitu paket wisata mengendarai ATV (Foto 4), paket hiking serta mengendarai becak.

Selain wisata alam, maka wisata budaya juga memiliki peran yang sangat penting dalam pengembangan wisata petanian berbasis subak di Desa Mengesta. Budaya yang masih kental dan unik terdapat di Desa Mengesta membuat daya tarik wisata di desa ini semakin besar. Budaya pertanian dengan budaya subaknya yang berlandaskan filosofis Tri Hita Karana telah menjadi bagian budaya masyarakat yang sebagian besar beragama Hindu.

Penetapan subak sebagai WBD dapat menjadikan masyarakat dan para petani terus bersemangat menjaga kelestarian subak. Sangat disayangkan memang jika suatu saat nanti sistem yang dahulu dibanggakan menjadi punah. Dengan kemajuan zaman yang semakin pesat ancaman kepunahan subak bukannya tidak mungkin terjadi. Oleh karena itu, semua aspek budaya yang berkaitan dengan subak harus dapat dilestarikan, seperti berbagai jenis upacara yang terkait dengan keberlangsungan sistem subak.

Hasil penelitian menunjukan bahwa masyarakat Desa Mengesta berkeinginan mengembangkan dan memanfaatkan sektor pariwisata secara sungguh-sungguh dan terlibat secara penuh. Sebagian besar masyarakat berharap dengan menjadi bagian WBD, pembangunan sektor pariwisata di Desa Mengesta dapat berkembang lebih baik. Memprioritaskan keterlibatan masyarakat akan dapat meningkatkan pendapatan mereka, misalnya dengan menjual produk olahan beras merah yang khas, souvenir atau pun sebagai 
tenaga kerja, sehingga dapat meningkatkan pendapatan mereka.

\section{Manfaat Status Warisan Budaya Dunia}

Menurut Windia dan Wiguna (2012:186), beberapa alasan ditetapkannya subak sebagai Warisan Budaya Dunia oleh UNESCO, adalah karena subak memiliki outstanding universal values, atau nilai-nilai budaya yang luar biasa yang masih hidup sampai sekarang. Nilai-nilai tersebut antara lain: authenticity atau nilai-nilai keaslian, subak merupakan budaya asli masyarakat Bali, dan universal value, bahwa budaya subak dapat diterima oleh semua lapisan masyarakat Bali, maupun masyarakat lainnya di dunia.

Filosofi Tri Hita Karana (THK) telah lama menjadi prinsip dan pendorong masyarakat Bali dalam menciptakan dan memelihara sistem irigasi pertanian, sehingga subak sering diidentikkan dengan sistem irigasi pertanian masyarakat Bali. Sistem pertanian di Bali, telah diakui mampu menciptakan keindahan lansekap yang spektakuler serta memberikan landasan ekologis yang berkelanjutan bagi peradaban Bali. Subak merupakan salah satu kearifan lokal masyarakat Bali, yang hingga kini masih eksis.

Masyarakat boleh bangga dengan diakuinya subak sebagai salah satu WBD oleh UNESCO. Hal tersebut membuktikan bahwa subak yang penuh dengan nilai-nilai kearifan lokal, tidak hanya diapresiasi secara lokal, tetapi juga secara nasional hingga internasional atau dunia melalui organisasi UNESCO. Bagi masyarakat petani di Desa Mengesta kebanggaan ditetapkannya subak sebagai WBD, tidak akan memberikan makna yang baik, apabila secara ekonomi predikat WBD tersebut tidak atau kurang memberikan manfaat.

Hasil penelitian menunjukkan bahwa dari 60 orang responden, ternyata sama sekali tidak ada (o,o\%) masyarakat yang merasakan bahwa penetapan subak sebagai WBD sangat bermanfaat bagi pengembangan ekonomi masyarakat Desa Mengesta. Selanjutnya sebanyak 1,7\% yang menyatakan penetapan subak sebagai WBD cukup bermanfaat bagi pengembangan ekonomi masyarakat Desa Mengesta, sebanyak 23,3\% menyatakan kurang bermanfaat; dan 38,3\% menyatakan tidak bermanfaat dan sebanyak 36,7\% yang menyatakan sangat tidak bermanfaat (Tabel 1).

Kondisi tersebut cukup memprihatinkan, karena tujuan penetapan subak sebagai WBD, hampir tidak dirasakan manfaatnya secara ekonomi oleh masyarakat. Kenyataan tersebut harus menjadi catatan penting bagi semua pihak terutama pemerintah baik kabupaten, provinsi maupun pusat, yang menjadi fasilitator dalam pembangunan di masyarakat. Pemerintah bersama masyarakat harus segera mencarikan solusi terbaik agar penetapan subak sebagai WBD memberikan manfaat ekonomi bagi masyarakat Desa Mengesta. 
Tabel 1. Manfaat Warisan Budaya Dunia Bagi Masyarakat

\begin{tabular}{|c|c|c|c|}
\hline No & Faktor & Kriteria & $\begin{array}{c}\text { Nilai } \\
\text { manfaat }\end{array}$ \\
\hline \multicolumn{4}{|c|}{ I MANFAAT WBD BAGI MASYARAKAT } \\
\hline \multirow{5}{*}{\multicolumn{2}{|c|}{1 Manfaat WBD }} & 1 Sangat tidak bermanfaat & $36,7 \%$ \\
\hline & & 2 Tidak bermanfaat & $38,3 \%$ \\
\hline & & 3 Kurang bermanfaat & $23,3 \%$ \\
\hline & & 4 Cukup bermanfaat & $1,7 \%$ \\
\hline & & 5 Sangat bermanfaat & $0,0 \%$ \\
\hline \multirow{5}{*}{2} & Jenis manfaat & 1 Tidak ada manfaat & $18,3 \%$ \\
\hline & yang dirasakan & 2 Bantuan pemerintah semakin besar & $41,7 \%$ \\
\hline & & 3 Investor mulai masuk ke Desa Mengesta & $13,3 \%$ \\
\hline & & 4 Harga tanah semakin mahal & $25,0 \%$ \\
\hline & & $\begin{array}{l}5 \text { Kunjungan wisatawan ke desa Mengesta sema- } \\
\text { kin banyak }\end{array}$ & $1,7 \%$ \\
\hline
\end{tabular}

Sumber: Hasil Analisis, 2015.

Hasil penelitian juga menunjukan bahwa, sekalipun secara ekonomi belum dirasakan manfaatnya oleh masyarakat, namun terdapat beberapa fakta lapangan yang dirasakan petani, sebagai dampak ditetapkannya subak sebagai WBD. Sebanyak 41,7\% masyarakat mengatakan adanya peningkatan bantuan pemerintah kepada masyarakat Desa Mengesta sejak ditetapkannya subak sebagai WBD. Subak yang masuk dalam kawasan WBD selain mendapatkan bantuan dana hibah sebesar Rp. 50 juta rupiah setiap tahun, telah mendapatkan bantuan hibah lainnya sebesar Rp.10ojuta per subak dari pemerintah Provinsi Bali pada tahun 2014.

Nampaknya bantuan tersebut tidak digunakan untuk membangun dan mengembangkan ekonomi subak, namun lebih banyak digunakan untuk kegiatan sosial keagamaan dan kegiatan fisik seperti perbaikan pura subak, jaringan irigasi. Padahal sesungguhnya bantuan pemerintah tersebut juga dapat digunakan untuk pembangunan ekonomi subak, seperti pengembangan koperasi tani, sarana usaha tani dan lain sebagainya. Kondisi tersebut menyebabkan masyarakat kurang atau tidak merasakan adanya manfaat ekonomi dengan ditetapkannya subak sebagai WBD.

Hasil penelitian menunjukan adanya kondisiyang kurang menguntungkan terkait dengan tujuan penetapan subak sebagai WBD, karena sebanyak 25,0\% masyarakat menyatakan bahwa harga tanah semakin mahal. Kenyataan tersebut dapat mendorong petani untuk menjual sawah, sehingga peluang meningkatnya alih fungsi lahan sawah akan semakin besar.

Kenyataan tersebut nampaknya telah dicermati dengan cukup baik oleh pemerintah, khususnya pemerintah kabupaten Tabanan, yang telah menerbitkan peraturan bupati (Perbup) No 27 tahun 2011 tentang lahan sawah berkelanjutan. Dalam Perbup tersebut secara jelas disebutkan 
larangan segala bentuk alih fungsi lahan subak yang berada di kawasan Catur Angga Batukaru. Berdasarkan Perda tersebut diharapkan alih fungsi lahan sawah, khususnya di kawasan WBD dapat dihindari, sekalipun harga tanah semakin meningkat dengan ditetapkannya subak sebagai WBD.

Desa Mengesta sebagai bagian WBD situs Catur Angga Batukaru menyoroti aspek khusus sistem subak yang memiliki ciri-ciri penting. Budaya pertanian dan ritual yang masih berjalan di masyarakat. Pertanian dan pariwisata dapat berjalan harmonis dengan masih eksisnya organisasi tradisional subak. Masyarakat petani Desa Mengesta dalam kegiatan pertaniannya masih menjaga kearifan lokal, hal tersebut tercermin dengan pertanian organiknya yang bertujuan untuk mengembalikan lingkungan lebih alami (sebelum Revolusi Hijau diberlakukan). Penerapan pertanian organik yang sudah berjalan di Desa Mengesta ini merupakan upaya untuk konservasi, keseimbangan dan keberlanjutan lingkungan. Penggunaan pupuk organik pada ekosistem subak, mampu mengembalikan tingkat kesuburan tanah. Aktivitas petani ini juga menunjukkan bahwa subak Wangaya Betan telah mengimplementasikan hubungan antara manusia dengan lingkungannya. Meskipun tidak dapat dipungkiri kondisi lingkungan pertanian yang terjadi di Desa Mengesta juga mengalami tantangan alih fungsi lahan karena adanya tuntutan ekonomi.

Sebanyak 48,3\% masyarakat menyatakan potensi dan daya tarik wisata sama sekali belum mampu meningkatkan pendapatan masyarakat. Sebanyak 40,0\% mengatakan hanya sebagian kecil saja potensi dan daya tarik wisata di Desa Mengesta yang mampu meningkatkan pendapatan masyarakat. Selanjutnya sebanyak $8,3 \%$ masyarakat yang menyatakan bahwa pengelolaan potensi dan daya tarik wisata hanya sebagian saja yang mampu meningkatkan pendapatan masyarakat. Hanya 3,3\% masyarakat yang mengatakan potensi dan daya tarik wisata yang telah dikelola, sebagian besar telah mampu meningkatkan pendapatan masyarakat.

Kondisi tersebut menggambarkan bahwa, sekalipun Desa Mengesta memiliki beberapa potensi dan daya tarik wisata, ternyata potensi pariwisata tersebut belum dikelola dengan baik, sehingga belum mampu meningkatkan pendapatan masyarakat. Sejalan dengan hasil FGD juga menunjukkan lemahnya pengelolaan pariwisata di Desa Mengesta sehingga belum mampu meningkatkan pendapatan masyarakat. Hal tersebut disebabkan karena sebagian besar kegiatan wisata yang ada di Desa Mengesta masih dikelola secara personal (pribadi atau pemilik) atau secara kelompok (pemaksan atau kelompok subak).

Pengelolaan tersebut kurang melibatkan masyarakat, sehingga masyarakat kurang merasakan manfaatnya. Selain itu sistem distribusi pendapatan dari pengelolaan potensi dan daya tarik wisata tersebut, juga belum jelas. Sebagai contoh Air Panas Belulang, yang belum dikelola dengan 
baik, sekalipun sudah dikenal oleh masyarakat dan wisatawan asing maupun domestik. Akan tetapi, pengelolaan dan pemanfaatan objek wisata tersebut masih terlihat sederhana. Fasilitas umum yang ada masih minim dan sangat sederhana. Tempat parkir yang sempit, warung-warung makan yang kurang tertata rapi. Kolam berendam dan fasilitas kamar mandi masih perlu perhatian dari segi kebersihan. Lingkungan yang relatif "kumuh" karena banyak sampah berserakan dan tidak dikelola dengan baik.

Desa Mengesta memiliki potensi dan daya tarik wisata yang cukup beragam, disertai dengan keinginan masyarakat yang demikian kuat untuk mengembangkan sektor pariwisata, bukan berarti bahwa tidak terdapat masalah dalam pelaksanaannya. Terkait dengan masalah SDM, disebabkan karena tingkat pendidikan dan pengetahuan masyarakat tentang sektor pariwisata yang rendah. Koordinasi antar subak dalam pengembangan sektor pariwisata juga sangat lemah serta kurangnya pemberdayaan petani dalam mengembangkan sektor pertanian yang bersinergis dengan sektor pariwisata. Kendala SDM tersebut hendaknya segera mendapatkan solusi. Masalah internal yang berkaitan dengan kelembagaan wisata lokal, antara lain: pokdarwis yang belum berfungsi secara optimal, lemahnya jejaring yang menangani pengembangan pariwisata, sehingga lemahnya sistem pemasaran pariwisata, serta rendahnya perhatian pemerintah daerah dalam pengembangan sektor pariwisata di Desa Mengesta.

Selanjutnya aspek eksternal yang menjadi masalah dalam pengembangan sektor pariwisata di Desa Mengesta antara lain (1) aksesibilitas, (2) sarana penunjang pariwisata, dan (3) masalah lingkungan. Banyaknya jalan yang menuju dan di dalam kawasan Desa Mengesta yang mengalami kerusakan cukup parah menyebabkan sulit atau rendahnya aksesibilitas ke Desa Mengesta. Kurangnya rumah makan, toko dan sarana kesenian, serta kurang atau terbatasnya tempat tinggal bagi wisatawan, yang sesungguhnya dapat diatasi melalui pengembangan homestay programme, yaitu dengan memanfaatkan rumah penduduk sebagai tempat akomodasi wisatawan.

Masalah yang berkaitan dengan aspek lingkungan, seperti alih fungsi lahan sawah, munculnya kandang ayam yang dibuat oleh masyarakat Desa Mengesta. Selain itu juga terdapat jaringan irigasi yang rusak yang perlu segera diperbaiki. Jaringan irigasi tersebut merupakan aspek mutlak yang harus segera mendapatkan solusinya seperti, perbaikian jaringan irigasi melalui sistem gotong-royong oleh anggota subak, maupun dengan bantuan pemerintah. Masalah kesehatan lingkungan juga tidak kalah penting, untuk segera mendapatkan penanganan atau solusi. Banyak terdapat sampah plastik, di sekitar saluran irigasi sehingga sangat mengganggu lingkungan. Kondisi tersebut harus segera mendapatkan penanganan oleh pemerintah, karena selain mengganggu lingkungan eksosistem subak, sebagai basis wisata pertanian, juga dapat mengganggu kesehatan masyarakat. 


\section{Peran Pemerintah dalam Pengembangan Pariwisata Berbasis Subak}

Peran pemerintah sangat penting dalam setiap proses pembangunan, termasuk dalam mengatur dan mengambil langkah-langkah kebijakan dalam pengelolaan subak Warisan Budaya Dunia Provinsi Bali. Peran pemerintah tersebut dapat diwujudkan dalam berbagai bentuk, seperti pengaturan dengan menerbitkan berbagai peraturan pemerintah, peraturan daerah, peraturan bupati, peraturan gubernur, dan lain sebagainya. Peran lainnya dapat dalam bentuk berbagai bantuan sosial kepada masyarakat, pendampingan, pembinaan, dan lain sebagainya.

Penetapan subak sebagai Warisan Budaya Dunia selain merupakan sebuah kebanggaan bagi masyarakat Bali, juga menjadi catatan sejarah yang sangat penting bagi bangsa Indonesia umumnya dan masyarakat Bali khususnya. Kebanggaan bagi masyarakat Bali, karena subak sebagai warisan leluhur masyarakat Bali, kini diakui oleh dunia internasional. Namun, apa artinya sebuah kebanggaan jika tidak mampu memberikan manfaat bagi kehidupan masyarakat Bali umumnya dan masyarakat anggota subak khususnya.

Untuk itu peran pemerintah dan berbagai stakeholder lain adalah sangat penting dalam meningkatkan pendapatan petani pengelola sistem subak, sehingga pekerjaan atau profesi sebagai petani, akan menjadi sebuah pilihan bagi masyarakat. Salah satu upaya yang dapat dilakukan adalah dengan memanfaatkan predikat WBD dalam pengembangan sektor pariwisata berbasis sistem subak, melalui fasilitasi dari pemerintah baik pusat maupun daerah.

Kebijakan pemerintah daerah terlihat dalam Peraturan Bupati (Perbup) Nomor 27 tahun 2011 tentang sawah berkelanjutan (sawah abadi). Inti dari Perbup tersebut adalah melarang segala bentuk alih fungsi lahan subak yang berada di kawasan Catur Angga Batukaru. Peran dan kewenangan pemerintah tersebut nampaknya belum mendukung dan berpihak kepada masyarakat atau petani, padahal masyarakat adalah aktor atau pemain kunci agar pertanian dan sawah tetap terjaga. Kurang berpihaknya Perbup tersebut karena, isinya lebih kepada larangan, bukan solusi terhadap masalah yang dihadapi masyarakat, apabila masyarakat dengan terpaksa harus mengalihfungsikan lahan pertaniannya.

Dalam upaya menjaga eksistensi subak di Bali menyusul semakin menyusutnya luasan lahan pertanian, maka pada tanggal 17 Desember 2012 Pemerintah Provinsi Bali telah mengeluarkan peraturan daerah yang khusus mengatur tentang pemberdayaan dan perlindungan subak. Perda tersebut sangat strategis dan mendesak untuk diberlakukan karena, melalui Perda tersebut diharapkan lahan subak sebagai warisan budaya Bali, sekaligus juga untuk lahan pertanian dapat dipertahankan keberlanjutannya. 
Peraturan Daerah tersebut tidak hanya berlaku untuk masyarakat subak di kawasan Desa Mengesta saja, melainkan untuk seluruh subak yang ada di Bali. Kondisi tersebut dapat dikatakan bahwa pemerintah belum berperan secara khusus dalam pengembangan sektor pariwisata berbasis subak di Desa Mengesta. Padahal bagi pemerintah daerah kehadiran pariwisata akan menciptakan lapangan kerja dan meningkatkan PAD (Pendapatan Asli Daerah). Kedua aspek tersebut merupakan aspek yang sangat penting bagi masyarakat dan pemerintah, seperti yang terjadi di kawasan WBD Jatiluwih.

Salah satu upaya yang dilakukan pemerintah daerah kabupaten Tabanan dalam meningkatkan kesejahteraan masyarakat di kawasan subak Jatiluwih sebagai bagian WBD Provinsi Bali, adalah terbitnya Peraturan Bupati (Perbub) No: 84 tahun 2013 tentang Penetapan Jatiluwih sebagai Daerah Tujuan Wisata (DTW) di Kabupaten Tabanan. Dalam Perbub tersebut telah diatur penggunaan uang hasil restribusi dari wisatawan yang datang ke Jatiluwih. Namun secara umum Peraturan Bupati tersebut belum sepenuhnya berpihak kepada petani pengelola lahan sawah di kawasan subak Jatiluwih. Terbukti bahwa petani di kawasan subak Jatiluwih hanya mendapatkan kurang dari 3\% dari dana yang masuk, setelah dikurangi dengan berbagai biaya pengelolaan (operasional).

Untuk kawasan Desa Mengesta, ternyata pemerintah daerah belum memberlakukan kebijakan seperti yang dilakukan untuk kawasan Jatiluwih. Sebagai bagian dari WBD dan memiliki letak strategis karena dekat dengan obyek wisata Jatiluwih. Desa Mengesta memiliki peluang dan potensi untuk dikembangkan sektor pariwisatanya. Pembangunan pariwisata yang terarah, yang dapat memberi manfaat bagi masyarakat serta menjamin pelestarian situs/kawasan.

Kebijakan lain yang dilakukan Pemerintah Daerah Provinsi Bali pascapenetapan WBD adalah dikeluarkannya kebijakan dengan memberikan bantuan langsung/hibah sebesar Rp.100.ooo.ooo di setiap subak di kawasan WBD pada tahun 2014 sesuai dengan SK Gubernur Bali No. 591/o3-H/ $\mathrm{HK} / 2014$, sedangkan subak lainnya di luar kawasan hanya mendapat Rp. 30.000.00o di setiap subak dan mulai tahun 2015 meningkat menjadi Rp. 50.000.00o yang sudah rutin dianggarkan oleh Pemerintah Provinsi Bali dan ditetapkan dalam SK Gubernur setiap tahunnya. Dengan demikian jelas terdapat perbedaan kebijakan yang diterapkan oleh pemerintah daerah dalam mengelola kawasan subak di Bali antara yang ada dalam kawasan WBD dengan yang di luar kawasan WBD.

Eksistensi subak sepenuhnya didukung oleh ketersediaan lahan untuk pertanian dan ketersediaan air irigasi. Kalau kedua faktor penentu ini sudah menunjukan indikasi yang negatif, maka hal itu dapat diartikan bahwa subak sedang mengalami proses ketidak-berlanjutan. Petani tetap miskin sementara investor meraup keuntungan besar dari aktivitas pariwisata, 
padahal jika tidak ada sawah dan petani, pariwisata tidak akan berkembang.

Seperti yang terjadi di kawasan subak WBD Jatiluwih. Sebelum ditetapkan sebagai WBD, sudah cukup dikenal wisatawan. Setelah ditetapkan sebagai bagian kawasan WBD, aktivitas pariwisata semakin pesat berkembang. Toko, restoran, tempat rekreasi hingga penginapan semakin banyak berdiri. Kebijakan pemerintah cenderung memberi ruang keberpihakan kepada investor. Jika kondisi ini dibiarkan akan menimbulkan kesenjangan ekonomi antara masyarakat lokal dengan pendatang.

Kondisi yang berbeda terjadi di Desa Mengesta sebagai bagian dari WBD, seharusnya peran pemerintah mulai ditingkatkan dalam mendorong pengembangan pariwisata di kawasan tersebut. Pembangunan sarana dan prasarana pariwisata akan mampu meningkatkan kunjungan wisatawan dan mendukung destinasi wisata. Sektor pariwisata akan berkembang lebih baik dan memberikan keuntungan bagi masyarakat lokal.

Semakin meningkatnya PBB, mengundang kontroversi dan menjadi salah satu pendorong terjadinya alih fungsi lahan pertanian. Bahkan, di kalangan petani dianggap sebagai beban yang secara perlahan mematikan sektor pertanian. Seperti yang diungkapkan Guru Besar Fakultas Pertanian Prof. Windia bahwa PBB adalah undang-undang pajak yang paling diskriminatif karena memihak investor dan mematikan kaum tani yang sudah berada dalam kondisi setengah hidup. Petani membayar pajak atas dasar nilai asetnya sehingga sulit untuk mencegah terjadinya alih fungsi lahan yang sudah dalam kondisi mengkhawatirkan. 4

Kebijakan pemerintah pasca penetapan WBD yang terkait pembebasan PBB bagi lahan subak sudah dirasakan bagi petani di kawasan DAS Pakerisan Kabupaten Gianyar. Pemerintah Kabupaten Gianyar telah mengeluarkan pembebasan PBB bagi 3 (tiga) subak di wilayahnya yang menjadi bagian WBD, yaitu subak Pulagan, subak Kulub Atas dan subak Kulub Bawah. Harapan ke depan hal tersebut dapat diikuti oleh Pemerintah Kabupaten Tabanan yang memiliki luasan dan jumlah subak terbanyak dalam situs Catur Angga Batukaru.

Pemerintah harus memiliki komitmen yang jelas dan tegas untuk membantu petani dalam menjaga kawasan subak. Memberikan berbagai subsidi seperti subsidi $\mathrm{PBB}$, subsidi sarana produksi pertanian, subsidi pendidikan, subsidi kesehatan serta bantuan untuk infrastruktur sistem subak, selain sebagai bentuk penghargaan kepada petani, juga sebagai upaya meningkatkan kesejahteraan petani berlandaskan ekosistem subak.

Hasil penelitian tentang persepsi masyarakat terhadap peran pemerintah menunjukan bahwa hanya 3,3\% pemerintah sepenuhnya berperan dalam

$4 \quad$ Antara News, 5 Maret 2015. "Subak Pertahankan Ruang Hijau Kontroversi Pajak PBB". [Diunduh 14 Maret 2015]. Sumber: http://www.antarabali. com/ berita/68947/subak-pertahankan-ruang-hijau- kontroversi-pajak-pbb 


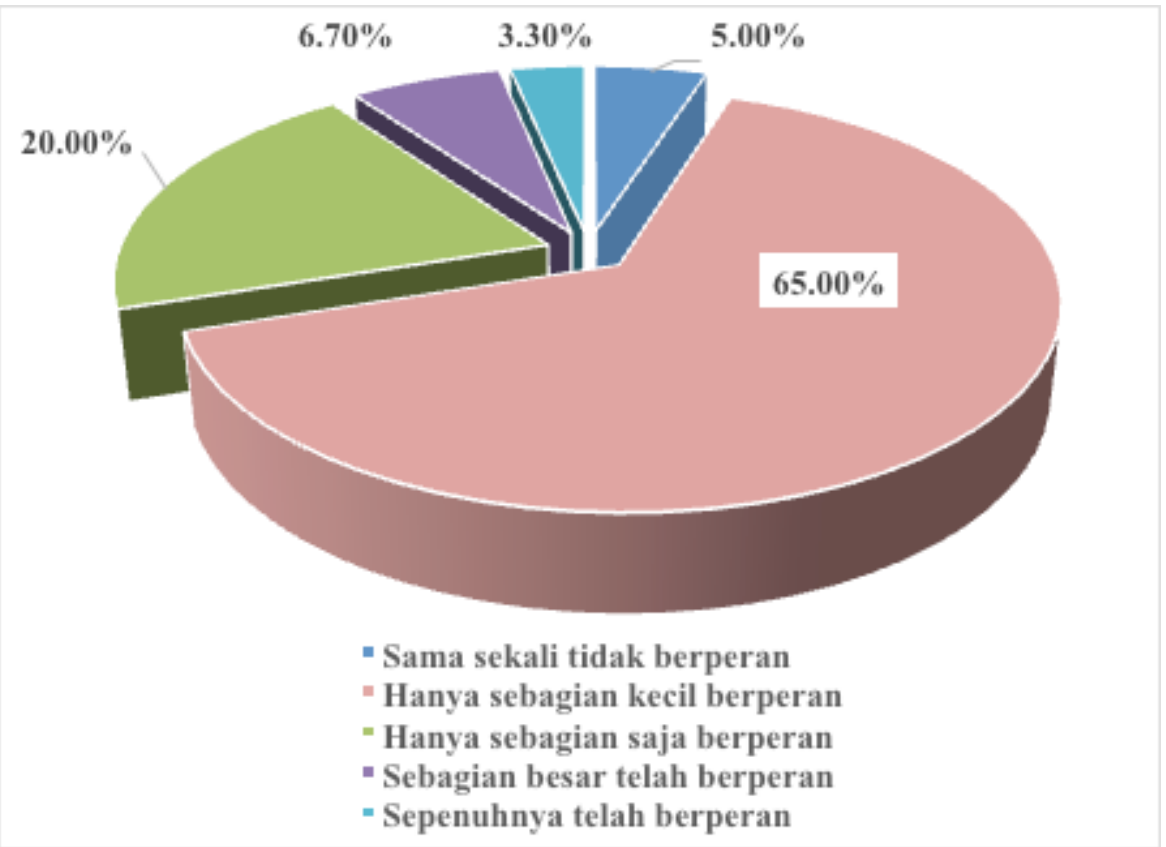

SUMBER: HASIL ANALISIS, 2015

Gambar 1. Persepsi Masyarakat terhadap Peran Pemerintah dalam Pengembangan Pariwisata di Desa Mengesta.

pengembangan pariwista di Desa Mengesta setelah ditetapkannya subak menjadi WBD (Gambar 1). Selanjutnya Gambar 1 juga menunjukan bahwa, sebanyak 6,7\% pemerintah sebagian besar telah berperan telah berperan dalam pengembangan pariwisata di Desa Mengesta; dan bahwa sebanyak 20,0\% peran pemerintah hanya sebagian saja. Persepsi masyarakat yang paling banyak $(65,0 \%)$ menunjukkan bahwa pemerintah hanya sebagian kecil telah berperan dalam pengembangan pariwisata di Desa Mengesta, bahkan terdapat sebanyak 5,0\% yang menyatakan pemerintah sama sekali belum berperan dalam pengembangan pariwisata di Desa Mengesta setelah ditetapkannya subak sebagai WBD.

Kondisi tersebut menggambarkan bahwa, sebagian besar masyarakat Desa Mengesta belum merasakan adanya peran pemerintah dalam pengembangan sektor pariwisata setelah ditetapkannya subak sebagai WBD. Hasil penelitian melalui survei sejalan dengan hasil penelitian melalui FGD, yang menyimpulkan bahwa pemerintah daerah kabupaten sampai ke tingkat pusat, hingga kini belum memberikan dukungan apapun terhadap pengembangan pariwisata di Desa Mengesta pasca ditetapkannya subak sebagai WBD.

Kenyataan tersebut juga terbukti, bahwa pemerintah kabupaten hingga ke tingkat pusat belum mengambil langkah apapun dalam mengembangkan sektor pariwasata di Desa Mengesta setelah ditetapkannya subak sebagai 
WBD. Baik dalam bentuk regulasi, bantuan pendanaan, pendampingan maupun pendidikan dan pelatihah bagi masyarakat yang bertujuan khusus untuk pengembangan pariwisata di Desa Mengesta. Hal tersebut menunjukan bahwa peran pemerintah relatif sangat terbatas, bahkan cenderung belum ada dalam mendukung pengembangan pariwisata di Desa Mengesta. Kondisi tersebut menyebabkan industri pariwisata juga belum berperan dengan baik dalam upaya peningkatan pendapatan masyarakat melalui pemanfaatan potensi dan daya tarik wisata di daerah tersebut.

Hasil penelitian melalui FGD dengan masyarakat Desa Mengesta, juga menunjukkan bahwa peran pemerintah kabupaten, provinsi dan pusat lebih banyak bersifat umum, atau tidak secara khusus ditujukan untuk Desa Mengesta dalam pengembangan pariwisata setelah ditetapkannya subak sebagai WBD. Peran pemerintah tersebut seperti perbaikan jalan utama Desa Mengesta menuju Jatiluwih sudah dilakukan dengan bantuan pemerintah sehingga jalur jalan utama yang melintasi Desa Mengesta menuju Jatiluwih dapat dilalui dengan lancar, meskipun masih banyak pula akses jalan yang rusak seperti jalan yang melintasi dusun Wangaya Betan menuju Jatiluwih.

Pemahaman masyarakat tentang peran pemerintah yang dirasakan masyarakat lebih dominan dalam bentuk peraturan. Sosialisasi tentang larangan adanya alih fungsi lahan pertanian, khususnya sawah di kawasan WBD setelah ditetapkannya subak sebagai WBD, kemungkinan besar merupakan dampak yang paling besar dirasakan masyarakat Desa Mengesta setelah ditetapkannya subak sebagai WBD. Hal tersebut memberikan penilaian masyarakat kepada pemerintah, yang hanya sebatas menerbitkan peraturan, yang berkaitan dengan pariwisata, karena umumnya masyarakat yang ingin mengalih-fungsikan lahan pertanian, pasca penetapan subak sebagai WBD adalah untuk kepentingan fasilitas pariwisata, seperti villa dan rumah makan.

Keberpihakan pemerintah dalam menjaga pelestarian subak sebagai WBD, sehingga sektor pertanian dapat bersinergis dengan pengembangan pariwisata relatif lamban. Pemerintah hanya gencar melakukan sosialisasi dan mengeluarkan kebijakan yang menyatakan subak telah ditetapkan sebagai WBD sehingga tidak boleh dialih-fungsikan ke non pertanian. Seharusnya masyarakat dan pemerintah memiliki komitmen dan tanggung jawab yang besar untuk menjaga pelestarian subak di dalam kawasan WBD. Nilai-nilai penting dari subak harus tetap terjaga dan lestari yang meliputi sawah, hutan, danau, sumber air dan berbagai pura sebagai wujud implementasi nilai-nilai Tri Hita Karana dalam sistem subak.

\section{Simpulan}

Subak memiliki posisi yang sangat penting dan strategis, sehingga perlu dilestarikan sejalan dengan tujuan penetapan subak sebagai WBD. Tiga ekosistem subak yang dimiliki Desa Mengesta yaitu: subak Paselatan, 
Wangaya Betan dan Piling memiliki pemandangan yang sangat indah dengan berbagai aktivitas pertanian yang dilakukan petani, sangat layak dijadikan sebagai wisata pertanian (agrowisata) berbasis subak. Selain itu sebanyak 70,0\% masyarakat Desa Mengesta menginginkan model pariwisata pertanian (agrowisata) berbasis subak yang perlu dikembangkan untuk meningkatkan pendapatan masyarakat di desa tersebut.

Manfaat status subak sebagai Warisan Budaya Dunia belum dirasakan secara optimal oleh masyarakat dalam pengembangan pariwisata berkelanjutan di Desa Mengesta. Terbukti hanya sebagian kecil (38\%) masyarakat yang merasakan adanya manfaat status subak sebagai WBD dalam pengembangan pariwisata berbasis subak. Bahkan, sebanyak $48,3 \%$ masyarakat menyatakan sama sekali tidak terlibat dalam mengelola potensi dan daya tarik wisata.

Pemerintah belum berperan secara optimal dalam mengelola potensi dan daya tarik wisata di Desa Mengesta. Terbukti sebanyak 65,0\% masyarakat Desa Mengesta, mengatakan hanya sebagian kecil adanya peran pemerintah dalam pengelolaan pariwisata setelah ditetapkan subak sebagai Warisan Budaya Dunia. Hal tersebut terbukti belum adanya langkah nyata pemerintah yang khusus ditujukan untuk pengembangan pariwisata di Desa Mengesta.

\section{Saran}

Perlu dilakukan penelitian dan kajian yang lebih detail tentang manfaat ekonomi, sosial dan lingkungan terhadap masyarakat di desa Mengesta sebagai akibat perkembangan pariwisata pertanian berbasis subak. Dan segera diambil langkah nyata untuk pengembangan wisata pertanian berbasis subak di Desa Mengesta, sebagai bagian dari WBD Provinsi Bali.

Manfaat status subak sebagai WBD dapat lebih dioptimalkan dalam pengembangan pariwisata berkelanjutan di Desa Mengesta. Hal tersebut dapat dilakukan melalui sosialisasi dan promosi pariwisata pertanian berbasis subak di Desa Mengesta, sebagai bagian dari WBD Provinsi Bali.

Meningkatkan peran pemerintah dan stakeholders pariwisata dalam pengelolaan dan pengembangan pariwisata di Desa Mengesta. Peningkatan peran pemerintah tersebut dapat dilakukan dengan menerbitkan regulasi yang secara khusus mengatur pengembangan pariwisata. Selain itu, juga dapat dilakukan dengan jalan memberikan bantuan pendanaan, pendampingan, pelatihan-pelatihan, dan pengadaan fasilitas penunjang pariwisata.

\section{Ucapan Terima Kasih}

Penulis menyampaikan terima kasih kepada Prof. Dr. I Nyoman Darma Putra, M. Litt selaku dosen Pembimbing I sekaligus Ketua Program Studi Magister Kajian Pariwisata Program Pascasarjana Universitas Udayana atas bimbingan, saran dan fasilitas yang diberikan selama studi. Terima kasih 
yang setulusnya penulis sampaikan kepada Dr. I Nyoman Madiun, M.Sc sebagai Pembimbing II atas masukan, koreksi dan dorongan semangat selama penelitian ini, serta kepada Dr. Alit Artha Wiguna, M.Si yang telah mengarahkan dan memberi banyak masukan untuk menyempurnakan tulisan ini. Tidak lupa diucapkan terima kasih kepada Pemerintah Provinsi Bali, atas kesempatan izin belajar dan dukungan beasiswa serta kepada seluruh staf pengajar yang telah memberikan ilmu dan wawasan mengenai kepariwisataan selama penulis menempuh perkuliahan.

\section{Daftar Pustaka}

Badan Pusat Statistik Kabupaten Tabanan. 2013. Kecamatan Penebel dalam Angka. Tabanan: Badan Pusat Statistik Kabupaten Tabanan.

Bungin, B. 2008. Penelitian Kualitatif: Komunikasi, Ekonomi, Kebijakan Publik, dan Ilmu Sosial Lainnya. Jakarta: Kencana.

Damardjati, R.S. 1995. Istilah-istilah Dunia Pariwisata. Jakarta: PT. Pradnya Paramitha.

Kementerian Kebudayaan dan Pariwisata RI. 2010. Nomination for inscription on the UNESCO World Heritage List. Cultural Landscape of Bali Province. Jakarta: Kementerian Kebudayaan dan Pariwisata RI.

Kementerian Pendidikan dan Kebudayaan RI. 2013. Rencana Pengelolaan Lansekap Budaya Provinsi Bali. Jakarta: Kementerian Pendidikan dan Kebudayaan RI.

Panglipur, Ratna Sri. 2012. Pendekatan Masyarakat Untuk Perencanaan Pariwisata Sangiran: Integrasi Pembangunan Pariwisata Berkelanjutan dan Pelestarian Situs. Jurnal Sangiran. Nomor 1, Hal. 128-137.

Paturusi, Syamsul Alam. 2008. Perencanaan Kawasan Pariwisata. Denpasar: Udayana University Press.

Pemerintah Provinsi Bali. 2012. Peraturan Daerah Provinsi Bali No. 2 Tahun 2012 tentang Kepariwisataan Budaya Bali.

Pemerintah Kabupaten Tabanan. 2011. Peraturan Bupati Tabanan No 27, tahun 2011 tentang Sawah Berkelanjutan.

Pemerintah Kabupaten Tabanan. 2011. Peraturan Bupati Tabanan No 35 tahun 2011 tentang Badan Pengelola Warisan Budaya di Kabupaten Tabanan

Pemerintah Kabupaten Tabanan. 2011. Peraturan Bupati Tabanan No 291 tahun 2011 tentang Pembentukan dan Susunan Keanggotaan Dewan Pengelola Warisan Budaya di Kabupaten Tabanan.

Pemerintah Kabupaten Tabanan. 2014. Profil Desa Mengesta. Tabanan: Pemerintah Kabupaten Tabanan.

Pemerintah Kabupaten Tabanan. 2013. Pola Tata Desa Mengesta. Tabanan: Pemerintah Kabupaten Tabanan.

Pitana, I Gede. 1993. Subak Sistem Irigasi Tradisional di Bali Sebuah Canangsari. Denpasar: Upada Sastra.

Prasiasa, Dewa Putu Oka. 2011. Wacana Kontemporer Pariwisata. Jakarta: Salemba Humanika.

Rangkuti, Freddy. 2005. Analisis SWOT Teknik Membedah Kasus Bisnis. Jakarta: Penerbit PT Gramedia. 
Sri Widari, Dewa Ayu Diyah. 2015. Perkembangan Desa Wisata Jatiluwih Setelah Penetapan Subak Sebagai Warisan Budaya Dunia. Tesis Pasca Sarjana Kajian Pariwisata. UNUD.

Steel, R.G.D. dan Torrie, J.H. 1991. Prinsip dan Prosedur Statistika. Jakarta: PT Gramedia Pustaka Utama

Suansri, P. 2003, Community Based Tourism Hand Book. Thailand : Rest Project Sukardi, Nyoman. 1998. Pengantar Pariwisata. STP Nusa Dua-Bali.

Sunaryo, Bambang. 2013. Kebijakan Pembangunan Destinasi Pariwisata, Konsep dan Aplikasinya di Indonesia. Yogyakarta : Penerbit Gava Media.

Swarbrooke. 1996. Pengembangan Pariwisata. Jakarta : Gramedia Pustaka Utama

Wingarta, P.S. 2006. Bali Ajeg. Ketahanan Nasional di Bali Konsepsi dan Implementasinya. Grafika Indah. Jakarta.

Wiguna, A.A. dan S.P. Kaler Surata. 2008. Multifungsi Ekosistem Subak dalam Pembangunan Pariwisata di Bali. Penerbit: Aksara Indonesia, Yogyakarta, kerjasama dengan Yayasan Somya Pertiwi, Bali. Cetakan I.

Windia dan Wiguna A.A. 2013. Subak Warisan Budaya Dunia. Denpasar: Udayana University Press.

Windia, I W. 2002. Transformasi Sistem Irigasi Subak yang Berlandaskan Konsep Tri Hita Karana. Disertasi Doktor Universitas Gajah Mada, Yogyakarta.

Yuliana, E. Dewi. 2010. Transformasi Pertanian (Tinjauan dari Proses dan Bentuk). Surabaya: Penerbit Paramita.

Yoeti, Oka A. 1996. Pengantar Ilmu Kepariwisataan. Bandung: Angkasa

Yoeti, Oka A. 2006. Pariwisata Budaya Masalah dan Solusinya. Jakarta: PT. Pradnya Paramitha.

\section{Profil Penulis}

Niluh Herawati, SS menyelesaikan sarjana sastra di Universitas Indonesia Jakarta (1999) dan saat ini bekerja pada instansi Pemerintah Provinsi Bali. 